\title{
SEMIVOLATILE COMPOUNDS IN SCHOOLS AND THEIR INFLUENCE ON COGNITIVE PERFORMANCE OF CHILDREN
}

\section{HANS-PETER HUTTER ${ }^{1}$, DANIELA HALUZA ${ }^{1}$, KATHRIN PIEGLER ${ }^{1}$, PHILIPP HOHENBLUM ${ }^{2}$, MARINA FRÖHLICH ${ }^{2}$, SIGRID SCHARF ${ }^{2}$, MARIA UHL ${ }^{2}$, BERNHARD DAMBERGER ${ }^{3}$, PETER TAPPLER ${ }^{3}$, MICHAEL KUNDI ${ }^{1}$, PETER WALLNER ${ }^{1,4}$, and HANNS MOSHAMMER ${ }^{1}$}

${ }^{1}$ Center for Public Health, Medical University Vienna, Vienna, Austria

Institute of Environmental Health

${ }^{2}$ Environmental Agency Austria, Vienna, Austria

${ }^{3}$ Austrian Institute for Healthy and Ecological Building, Vienna, Austria

${ }^{4}$ Medicine and Environmental Protection, Vienna, Austria

\begin{abstract}
Objectives: WHO's Children's Environment and Health Action Plan for Europe (CEHAPE) focuses on improvements of indoor environments where children spend most of their time. To investigate the relationship between school indoor air pollutants and cognitive performance in elementary school children, a multidisciplinary study was planned in all-day schools in Austria. Materials and Methods: In a cross-sectional study (LuKi study: Air and Children) indoor air pollutants were monitored in nine elementary all-day schools in urban and rural regions of Austria. In addition, school dust and suspended particulates $\left(\mathrm{PM}_{10}, \mathrm{PM}_{2.5}\right)$ were measured, focusing on semivolatile compounds (e.g. phthalates, phosphororganic compounds $[\mathrm{POC}]$ ). Health status and environmental conditions were determined by parents' questionnaire, cognitive function was measured by Standard Progressive Matrices (SPM). Results: Overall, 596 children (6-8 years of age) were eligible for the study. Cognitive tests were performed in 436 children. Analysis showed significant correlations of tris(2-chlorethyl)-phosphate (TCEP) in $\mathrm{PM}_{10}$ and $\mathrm{PM}_{25}$ and school dust samples with cognitive performance. Cognitive performance decreased with increasing concentrations of TCEP. Furthermore, cognitive function decreased significantly with increasing $\mathrm{CO}_{2}$ levels. Conclusions: POC are widely used as plasticizers, flame retardants and floor sealing. This is the first report of a correlation between TCEP in indoor air samples and impairment of cognitive performance in school children. As a precautionary measure, it is recommended to prohibit the use of toxic chemicals and those suspected of a toxic potential in children's environments such as schools.
\end{abstract}

Key words:

Children's health, Cognitive performance, Indoor air pollution, Semivolatile compounds, TCEP

\section{INTRODUCTION}

Healthy environments for children have been a focus of the World Health Organization (WHO) during the last years. The WHO Children's Environment and Health
Action Plan for Europe (CEHAPE) aims to protect the health of children and young people from environmental hazards [1,2]. Regional Priority Goals of this action plan include prevention and reduction of illnesses caused by

This work was supported by the Federal Ministry of Agriculture, Forestry, Environment and Water Management and the Government of the County of Carinthia. Received: July 19, 2012. Accepted: May 15, 2013.

Corresponding author: H. Moshammer, Institute of Environmental Health, Center for Public Health, Medical University of Vienna, Kinderspitalgasse 15, A-1090 Vienna, Austria (e-mail: hanns.moshammer@meduniwien.ac.at). 
indoor and outdoor air pollution, and reduction of risks arising from exposure to hazardous chemicals.

The impact of indoor pollutants on wellbeing and health of children has been addressed [3-7]. In particular, the long hours children spend in schools makes the assessment of indoor air quality in this setting a relevant target of research and evaluation.

Many air pollutants like solvents and other volatile organic compounds (VOCs) have been implicated as neurotoxic [8]. There are also hints, especially from animal studies, that phosphororganic compounds (POCs), in particular TCEP (tris(2-chlorethyl)-phosphate), may be neurotoxic [9-13]. POCs have a wide spectrum of indoor use, including use as flame retardants, plasticizers, and floor sealing. In public buildings (e.g. schools), levels of exposure to POCs are higher compared with domestic buildings $[14,15]$.

The present study (LuKi-study: Air and Children) was undertaken a) to quantify indoor pollution in elementary schools (with a special focus on semivolatile compounds like POCs), and b) to explore the influence of indoor air pollutants on health and cognitive performance. It was hypothesized that exposure to POCs was associated with impaired cognitive performance. A report about other endpoints of the LuKi study has been published previously [16].

\section{MATERIALS AND METHODS}

\section{Participants and questionnaire}

The cross-sectional study was conducted in all-day elementary schools for first and second graders in Austria. To select study sites, meetings with school authorities, headmasters and teachers were held. Out of the 19 schools that expressed their willingness to participate, nine schools were selected in order to include communities of different sizes ( $>1 \mathrm{~m}$, large and mediumlarge cities, and rural communities). The participating schools were located in different urban (Vienna, Graz, St. Pölten) and rural (Carinthia) regions. In each school, two classes were selected (one first and one second school year).

Teachers forwarded consent forms to the parents/guardians together with the questionnaire. Parents/guardians returned the signed agreement and the parents' questionnaire in a sealed envelope to the teacher. Both were handed over to the study team at the time of the measurement campaign.

Children were 6 to 8 years of age. Fifty-four percent of the children were living in densely populated areas. Sixty-four percent of mothers and $55 \%$ of fathers had 12 or more years of education (Table 1).

Table 1. Demographic characteristics of study participants

\begin{tabular}{lc}
\hline \multicolumn{1}{c}{ Parameters } & $\begin{array}{c}\text { Respondents } \\
(\mathrm{N}=436)\end{array}$ \\
\hline Age $(\mathrm{M} \pm \mathrm{SD})(\mathrm{n})$ & \\
male & $7.17 \pm 0.68$ \\
female & $7.20 \pm 0.62$ \\
Gender $(\mathrm{n})$ & \\
male & 218 \\
$\quad$ female & 218 \\
Education $\geq 12$ years $(\%)$ & \\
father's education & 55 \\
mother's education & 64 \\
\hline
\end{tabular}

The study was approved by the Ethics-Committee of the Medical University of Vienna and the Vienna General Hospital (permit no. EK492/2006).

\section{Building investigations}

The nine school buildings were inspected by technicians and environmental medicine experts using a checklist regarding building characteristics, the classroom layout, surface materials, mold or water damages, environmental conditions and other building-related items. 


\section{Cognitive test}

The cognitive evaluation was accomplished by means of the Standard Progressive Matrices test [17]. The SPM is a non-verbal assessment tool to measure the reasoning component of general intelligence. It comprises a series (A to E) of problems of increasing complexity and difficulty. Each item of this test consists of a pattern or matrix with one piece missing. The task is to complete the pattern by choosing from a list of options. Parts D and E of the test were not used as these parts require the ability to reason in analogies which is developed only in rudimentary form in children under the age of 11 years. Besides inductive reasoning, spatial abilities play a certain role in SPM achievements.

Two trained psychologists applied these tests in the schools according to the recommended procedure for group application. Although the test normally lasts approximately 45 minutes, the children were told that there is no time limit, however, all pupils completed the series of tests within 45 minutes.

\section{Collection and analysis of indoor air pollutants}

Besides indoor climate factors (temperature, humidity), 252 indoor chemical parameters were measured. The measured chemical parameters included inter alia substance groups like aromatic, aliphatic and chlorinates hydrocarbons, alcohols, aldehydes, terpenes, volatile compounds in PM/school dust, synthetic musks, phenols, phthalates, trisphosphates, $\mathrm{PAH}, \mathrm{PCB}$, organohosphorous esters, pesticides, polybrominated diphenyl ethers, organotins, metals, inorganic components, industrial chemicals, disinfectants. Measurements were conducted in the classrooms where pupils from stay six to seven hours per day except for lunch, sports and other outdoor activities. Two classrooms were selected per school and all classrooms were sampled twice in different seasons (autumn and spring).
Carbon dioxide, particulate matter, indoor humidity, and temperature were continuously monitored in the classrooms for two one-week periods.

Additional samples of particulates were collected on two days in two rooms for $24 \mathrm{~h}$ for detailed chemical analysis. Samples of particulate matter $\left(\mathrm{PM}_{10}, \mathrm{PM}_{2.5}\right)$ were collected by means of glass fiber filters (Whatman) attached to Digitel High Volume samplers. Samples were collected from 0:00 to 24:00 with a flow rate of approx. $30 \mathrm{~m}^{3} / \mathrm{h}$. The total volume of air aspired by the filters was approx. $730 \mathrm{~m}^{3}$. Due to the noise associated with the sampling, side rooms of the classrooms were chosen. Teachers were advised to keep the doors open during the time of sampling to guarantee air exchange. The location of measurement apparatus was selected by the expert team to ensure that the samples were representative for the indoor air the children were exposed to.

For every sample a daily average of $\mathrm{PM}_{10}$ and $\mathrm{PM}_{2.5}$ concentration was determined gravimetrically. The applied method corresponds to the reference method used in outdoor air measurements $[18,19]$. Filters were conditioned $\left(20 \pm 1^{\circ} \mathrm{C}\right.$, relative humidity $\left.50 \pm 5 \%\right)$ for a period of $48 \mathrm{~h}$ prior to weighing.

Classroom dust was sampled by school personnel by means of special industrial vacuum cleaners according to a sampling instruction once a day during one week. Samples were provided in dust pockets. Household dust was sieved to a fraction $<63 \mu$ m which was used for analytical preparation.

The screening of particulate matter and classroom dust involved inter alia semivolatile compounds (e.g. PCBs, phthalates, trisphosphates, PAHs, synthetic musks). The method is a modification of EPA method 8270. Filter samples were extracted in the laboratory using dichlormethane. In this way, about 150 individual compounds could be quantified. Samples were analyzed by means of gas chromatography - mass selective detection. Data acquisition was carried out in SIM mode; substances were 
identified by their retention time and by mass fragments and their response ratio.

In addition, volatile organic compounds (VOCs) and aldehydes were measured in air samples from the classrooms. VOCs were sampled by passing air through activated charcoal tubes (ORBO-32 S Supelco) according to the Austrian Standard ÖNORM M 5700-2. Sample flow rates were approx. $25 \mathrm{l} / \mathrm{h}$. The VOCs were extracted from activated carbon with $\mathrm{CS}_{2}$, methanol and dichlormethane. Analysis was performed using GC/MS (SIM mode). Details of the measurement procedure have been published elsewhere [16].

\section{Statistical analysis}

Collected data were analyzed using the Statistical Package STATA 9.2 (StataCorp) and SPSS 18.0 for Windows (SPSS Inc. Chicago IL, USA).

Due to the large number of indoor air quality indicators measured (overall 252 indicators), only those that showed substantial variation across schools were considered in the analyses of the relationship with cognitive performance. A ratio of 4 of the betweenschool to the pooled within-school variance was chosen as the criterion. These were, in air samples: formaldehyde, ethylbenzene, n-decane; in $\mathrm{PM}_{10}, \mathrm{PM}_{2.5}$ or classroom dust samples: benzo(a)pyrene, phenanthrene, TDCPP, and TCEP. In addition, $\mathrm{CO}_{2}$ as a continuously measured indicator of classroom ventilation was analyzed.

For analyzing the SPM outcome, the raw scores were converted to $\mathrm{T}$ scores based on the age-related standards. Multivariate linear regression was performed with social status (parental education and occupation), gender, and region (population density) included as potential confounders. Results were expressed as partial correlation coefficients for the air pollutant. P-values below 0.05 were considered significant.

\section{RESULTS}

Overall 596 children (6 to 8 years of age; 306 boys and 290 girls; 318 first graders, 278 second graders) were eligible for the study. Four hundred forty-nine questionnaires $(75.3 \%)$ were returned. SPM was applied in 436 children (73.2\%; 218 boys and girls each; 225 first graders, 211 second graders). Demographic characteristics are shown in Table 1.

$\mathrm{PM}_{10}$ concentrations (daily mean values) in schools ranged from $2 \mu \mathrm{g} / \mathrm{m}^{3}$ to $62 \mu \mathrm{g} / \mathrm{m}^{3}$ (median: $29 \mu \mathrm{g} / \mathrm{m}^{3}$ ), $\mathrm{PM}_{2.5}$ concentrations ranged from 1 to $34 \mu \mathrm{g} / \mathrm{m}^{3}$ (median: $12 \mu \mathrm{g} / \mathrm{m}^{3}$ ). $\mathrm{CO}_{2}$ concentrations (1-hour-moving average) ranged from 350 to $3300 \mathrm{ppm}$ and daily mean values were from 500 to $1400 \mathrm{ppm}$.

With regard to VOC and aldehydes, almost all compounds investigated were above the limit of quantification (LOQ). The following substances were above the 90th percentile of the German AGOeF data base [20] in more than three measurements: acetophenone (11 samples), n-decane (13 samples), and formaldehyde (4 samples).

Out of the polybrominated diphenylethers, PBDE 209 showed by far the highest concentrations (median values in school dust: $600 \mu \mathrm{g} / \mathrm{kg}$ range: < LOQ - $2300 \mu \mathrm{g} / \mathrm{kg}$; in $\mathrm{PM}_{10}: 300 \mu \mathrm{g} / \mathrm{kg}$; in $\mathrm{PM}_{2.5} 275 \mu \mathrm{g} / \mathrm{kg}$ ). As to phthalates, the highest values in classrooms dust were found for diethylhexylphthalte (DEHP: median $3350 \mathrm{mg} / \mathrm{kg}$ ) with values ranging between 750 and $7260 \mathrm{mg} / \mathrm{kg}$ (median in $\mathrm{PM}_{10}: 10000 \mathrm{mg} / \mathrm{kg} ; \mathrm{PM}_{2.5}: 19000 \mathrm{mg} / \mathrm{kg}$ ).

Within the group of phosphororganic compounds, Tris(2-chlorethyl)phosphate TCEP was found at higher concentrations in almost all samples, similar to another trisphosphate reaching the statistical criterion (Tris(1,3-dichlor-2-propyl)-phosphate TDCPP). Results of measurement for these phosphororganic compounds as well as for classical indoor air pollutants (formaldehyde, ethylbenzene, n-decane, benzo(a)-pyrene, phenanthrene) for which the criterion was fulfilled are summarized in Table 2. 
Table 2. Pollutants analyzed (measurements above LOQ out of 36, minimum, maximum, and median)*

\begin{tabular}{|c|c|c|c|c|c|c|c|}
\hline Source & Substance & $>$ LOQ & $\operatorname{Min}^{b}$ & $\mathrm{Max}^{\mathrm{b}}$ & $\mathrm{P} 50^{\mathrm{b}}$ & $r_{\text {part }}$ & $\mathrm{p}$ \\
\hline Air & $\mathrm{CO}_{2}$ & 36 & 500.0 & 1400.0 & 840.0 & -0.102 & 0.034 \\
\hline Air & formaldehyde & 35 & 6.5 & 136.5 & 29.8 & 0.061 & 0.215 \\
\hline Air & ethylbenzene & 35 & 0.5 & 10.3 & 1.5 & -0.096 & 0.051 \\
\hline Air & n-decane & 35 & 0.8 & 245.4 & 6.6 & -0.068 & 0.169 \\
\hline $\mathrm{PM}_{10}$ & phenanthrene & 11 & $<$ LOD & 6.0 & $<\mathrm{LOD}$ & -0.090 & 0.067 \\
\hline $\mathrm{PM}_{10}$ & benzo(a)pyrene & 22 & $<\mathrm{LOD}$ & 38.0 & 5.0 & -0.081 & 0.098 \\
\hline $\mathrm{PM}_{10}$ & TCEP & 35 & $<\mathrm{LOD}$ & 4700.0 & 141.0 & -0.147 & 0.003 \\
\hline $\mathrm{PM}_{10}$ & TDCPP & 35 & $<\mathrm{LOD}$ & 4200.0 & 90.0 & -0.083 & 0.091 \\
\hline $\mathrm{PM}_{2.5}$ & phenanthrene & 10 & $<\mathrm{LOD}$ & 12.0 & $<\mathrm{LOD}$ & -0.097 & 0.047 \\
\hline $\mathrm{PM}_{2.5}$ & TCEP & 35 & 54.0 & 11000.0 & 522.0 & -0.149 & 0.002 \\
\hline $\mathrm{PM}_{2.5}$ & TDCPP & 35 & 29.0 & 16000.0 & 164.0 & -0.088 & 0.242 \\
\hline Dust & TCEP & 36 & 0.6 & 35.0 & 2.5 & -0.154 & 0.002 \\
\hline
\end{tabular}

* Partial correlation coefficients ${ }^{\mathrm{a}}$ from multivariate regression and p-values for the relationship between concentrations of selected substances and cognitive performance (standardized SPM values).

${ }^{a}$ Corrected for social status, gender and region (urban/rural).

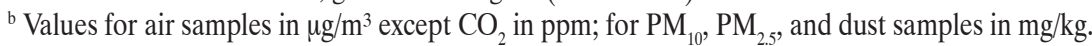

LOD - limit of detection; LOQ - limit of quantification; SPM - Standard Progressive Matrices.

Average T scores of the SPM were 47.7 (SD: 8.60) for boys and 46.1 (SD: 8.53) for girls. The difference between boys and girls was not significant. Results of the regression analyses of the relation between $\mathrm{T}$ scores and concentrations of selected indoor pollutants were as follows (Table 2): Analysis revealed significant correlations of tris(2-chlorethyl)phosphate (TCEP) in classroom dust and filter samples $\left(\mathrm{PM}_{10}\right.$ as well as $\left.\mathrm{PM}_{2.5}\right)$ with cognitive performance. Cognitive performance decreased with increasing concentrations of TCEP. Furthermore, a significant correlation was found with phenanthrene concentrations in $\mathrm{PM}_{2.5}$. Also $\mathrm{CO}_{2}$ showed a negative relation to performance.

\section{DISCUSSION}

Indoor air in schools may affect the health of children and their learning performance. At present, data about the effects of semivolatile compounds in schools' air are sparse. This is the first report of a correlation between the concentration of the phosphororganic compound tris(2-chlorethyl)-phosphate (TCEP) in indoor samples (classroom dust, $\mathrm{PM}_{10}$, and $\mathrm{PM}_{2.5}$ ) and impairment of cognitive performance in school children.

The widespread use of such chemicals can lead to their relatively high concentrations in house dust $[9,14]$.

A case report on neurotoxic effects of TCEP on humans is mentioned in the EU risk assessment report: A five-year-old girl developed neurogenic defects after TCEP exposure (her sleeping room was equipped with wood panelling treated with 3\% TCEP) [9]. After the removal of all timber panels, the clinical status of the child improved. Two years later, no functional deficits were present.

Based on animal studies, however, the EU risk assessment report concluded that there is a sufficient margin of safety for children's exposure to TCEP via inhalation (and other routes) [9]. Since 2010, TCEP is listed as SVHC-substance (Substance of Very High Concern) in the candidate list for authorization under the European REACH regulation [21,22]. 
In our study, we also found associations of phenanthrene, a polycyclic aromatic hydrocarbon, with cognitive performance. To our knowledge, no such correlation has been reported so far. There are, however, indications from animal studies $[23,24]$ as well as from cohort studies $[25,26]$ that prenatal exposure to polycyclic aromatic hydrocarbons may cause neurodevelopmental and behavioral effects.

Taken together, this investigation suggests a possible negative impact of TCEP on the cognitive performance of elementary school children. Although TCEP has been substituted in many applications by TCPP (Tris(2-chlorpropyl) phosphat) [21], it still plays a role in indoor air. Concentrations of TCEP in schools were higher than those of TCPP. Also $\mathrm{CO}_{2}$ had a negative association to cognitive performance. During class activities, concentrations increased often above the 1000 ppm level that is considered to indicate poor ventilation and thus may point to adverse effects of insufficient ventilation.

Phosphororganic compounds (POCs) are widely used as plasticizers, flame retardants and floor sealings. This is the first report of a correlation between the concentration of a POC (Tris(2-chlorpropyl)phosphate, TCEP) in indoor air samples and impairment of cognitive performance in school children. Recently TCEP was listed by the EU as substance of very high concern because of its CMR properties (reproduction toxicity) [21]. Canada concluded that, on the basis of the carcinogenicity of TCEP, the substance may constitute a danger to human life or health [27]. New York's TRIS-Free Children and Babies Act prohibits the sale of products containing TRIS (including TCEP) intended for use by a child three years of age or younger starting December 1, 2013 [28].

More research is needed on the relationship between TCEP exposure and cognitive functions.

Following the precautionary principle and in the view of the new regulations, it would be prudent to restrict the use of TCEP especially in children's environments such as schools and day care centers.

\section{REFERENCES}

1. World Health Organization. Children's Environment and Health Action Plan for Europe (document EUR/04/5046267/7). Fourth Ministerial Conference on Environment and Health; 2004 Jun 23-25; Budapest, Hungary. Copenhagen: WHO Regional Office for Europe; 2004 [cited 2013 March 7]. Available from URL: http://www.euro.who.int/document/e83338.pdf.

2. World Health Organization. Health and Environment in Europe: Progress assessment. Copenhagen: WHO Regional Office for Europe; 2010.

3. Daisey JM, Angell WJ, Apte MG. Indoor air quality, ventilation and health symptoms in schools: An analysis of existing information. Indoor Air. 2003;13:53-64, http://dx.doi. org/10.1034/j.1600-0668.2003.00153.x.

4. Environmental Health Criteria. Principals for evaluating health risks in children associated with exposure to chemicals. Environmental Health Criteria 237. Geneva: WHO; 2006.

5. Mendell MJ, Heath GA. Do indoor pollutants and thermal conditions in schools influence student performance? A critical review of the literature. Indoor Air 2005;15:27-52, http:// dx.doi.org/10.1111/j.1600-0668.2004.00320.x.

6. Sundell J, Levin H, Nazaroff WW, Cain WS, Fisk WJ, Grimsrud DT, et al. Commemorating 20 years of indoor air. Ventilation rates and health: Multidisciplinary review of the scientific literature. Indoor Air. 2011;21:191-204, http://dx.doi. org/10.1111/j.1600-0668.2010.00703.x.

7. World Health Organization. WHO guidelines for indoor air quality: Selected pollutants [cited 2013 Aug 12]. Available from URL: http:// www.euro.who.int/_data/assets/pdf_file/0009/128169/e94535.pdf.

8. World Health Organization. Effects of air pollution on children's health and development. WHO Special Programme Environment and Health. Bonn: European Centre for Environment and Health; 2005.

9. European Community. European Union Risk Assessment Report, Tris (2-chlorethyl) phosphate, TCEP. CAS-No.: 115-96-8, EINECS-No.: 204-118-5. Final approved version. Luxembourg: Office for Official Publications of the European Communities; July 2009. 
10. Matthews HB, Dixon D, Herr DW, Tilson H. Subchronic toxicity studies indicate that tris(2-chloroethyl)phosphate administration results in lesions in the rat hippocampus. Toxicol Ind Health. 1990;6:1-15.

11. Matthews HB, Eustis SL, Haseman J. Toxicity and carcinogenicity of chronic exposure to tris(2-chloroethyl)phosphate. Fundam Appl Toxicol. 1993;20:477-85, http://dx.doi. org/10.1006/faat.1993.1058.

12. Tilson HA, Veronesi B, McLamb RL, Matthews HB. Acute exposure to tris(2-chloroethyl)phosphate produces hippocampal neuronal loss and impairs learning in rats. Toxicol Appl Pharmacol. 1990;106:254-69, http://dx.doi. org/10.1016/0041-008X(90)90245-P.

13. National Toxicology Program. Toxicology and carcinogenesis studies of tris(2-chloroethyl)phosphate (CAS No. 115-96-8) in F344/N rats and $\mathrm{B}_{6} \mathrm{C}_{3} \mathrm{~F}_{1}$ mice (gavage studies). Technical report series No. 391. North Carolina: US Department of Health and Human Services; 1991.

14. Marklund A, Andersson B, Haglund P. Organophosphorus flame retardants and plasticizers in air from various indoor environments. J Environ Monit. 2005;7:814-9, http://dx.doi. org/10.1039/b505587c.

15. Sagunski H, Rosskamp E. Richtwerte für die Innenraumluft: Tris(2-chlorethyl)phosphat. Bundesgesundheitsblatt Gesundheitsforsch Gesundheitsschutz. 2001;45:300-6.

16. Environmental Agency Austria. [Air and Children: indoor air quality in all-day schools and children's health]. In: Hohenblum P, Kundi M, Gundacker C, Hutter H-P, Jansson M, Moosmann L, et al. editors. Report REP-0182. Vienna: EAA; 2008. German.

17. Raven J, Raven JC, Court JH. Manual for Raven's Progressive Matrices and Vocabulary Scales. San Antonio, TX: Pearson Assessment; 2004.

18. VDI - The Association of German Engineers. VDI-guideline DIN EN 12341. Air quality - Determination of the PM10 fraction of suspended particulate matter - Reference method and field test procedure to demonstrate reference equivalence of measurement methods. Duesseldorf: VDI; 1998.
19. VDI - The Association of German Engineers. VDI-guideline DIN NORM EN 14907. Ambient air quality - Standard gravimetric measurement method for the determination of the $\mathrm{PM}_{2.5}$ mass fraction of suspended particulate matter. Duesseldorf: VDI; 2005.

20. AGOeF - Association of Ecological Research Institutes. AGOeF Guidance values for volatile organic compounds in indoor air [cited 2008 Aug 1]. Available from URL: http:// agoef.de/agoef/oewerte/orientierungswerte_englisch.html.

21. European Chemicals Agency. Candidate list of substances of very high concern for authorisation [cited 2013 March 7]. Available from URL: http://echa.europa.eu/web/guest/addressing-chemicals-of-concern/authorisation/substances-ofvery-high-concern-identification/candidate-list-of-substances-of-very-high-concern-for-authorisation.

22. European Chemicals Agency. Member state committee support document for identification of Tris (2-chloroethyl)phosphate as substance of very high concern because of its CMR properties [cited 2009 Aug 1]. Available from URL: http:// echa.europa.eu/doc/candidate_list/svhc_supdoc_tris_phosphate_publication.pdf.

23. Brown LA, Khousbouei H, Goodwin JS, Irvin-Wilson CV, Ramesh A, Sheng L, et al. Down-regulation of early ionotrophic glutamate receptor subunit developmental expression as a mechanism for observed plasticity deficits following gestational exposure to benzo(a)pyrene. Neurotoxicology. 2007;28:965-78, http://dx.doi.org/10.1016/j.neuro.2007. 05.005 .

24. Wormley DD, Chirwa S, Nayyar T, Wu J, Johnson S, Brown LA, et al. Inhaled benzo(a)pyrene impairs long-term potentiation in the F1 generation rat dentate gyrus. Cell Mol Biol. (Noisy-le-grand) 2004;50:715-21.

25. Edwards SC, Jedrychowski W, Butscher M, Camann D, Kieltyka A, Mroz E, et al. Prenatal exposure to airborne polycyclic aromatic hydrocarbons and children's intelligence at 5 years of age in a prospective cohort study in Poland. Environ Health Perspect. 2010;118:1326-31, http://dx.doi.org/10.1289/ ehp.0901070. 
26. Perera FP, Wang S, Vishnevetsky J, Zhang B, Kathleen J, Cole KJ, et al. Polycyclic aromatic hydrocarbons-aromatic DNA adducts in cord blood and behavior scores in New York City children. Environ Health Perspect. 2011;119:1176-81, http://dx.doi.org/10. 1289/ehp.1002705.

27. Environment Canada and Health Canada. Evaluating Existing Substances. Screening Assessment for the Challenge. Tris(2-chloroethyl) phosphate (TCEP) [cited 2009 Aug 1].
Available from URL: http://www.ec.gc.ca/ese-ees/default. asp?lang $=\mathrm{En} \& \mathrm{xml}=\mathrm{C} 378778 \mathrm{~A}-\mathrm{D} 834-54 \mathrm{E} 0-7 \mathrm{~F} 69-\mathrm{E} 6 \mathrm{E}-$ 2944A74FC.

28. New York State Assembly. Bill No. A06195A. An act to amend the environmental conservation law, in relation to prohibiting the sale of child products containing TRIS [cited 2013 March 7]. Available from: http://www.assembly. state.ny.us/leg/?default_fld $=\& b n=A 06195 \&$ term $=2011 \& S$ ummary $=\mathrm{Y} \&$ Actions $=\mathrm{Y} \&$ Votes $=\mathrm{Y} \& \mathrm{Memo}=\mathrm{Y} \&$ Text $=\mathrm{Y}$.

This work is available in Open Access model and licensed under a Creative Commons Attribution-NonCommercial 3.0 Poland License - http://creativecommons.org/ licenses/by-nc/3.0/pl/deed.en. 